\title{
Review on China's renewable energy and future projections
}

\author{
Jinfeng Zhang*, Adu Daniel ${ }^{\mathrm{a}}$, Yujian Fang $^{\mathrm{a}}$, Appiah Desmond ${ }^{\mathrm{a}}$,Eric .O. Antwi ${ }^{\mathrm{b}}$ \\ ${ }^{a}$ National Research Center of Pumps, Jiangsu University, Zhenjiang 212013, \\ ${ }^{b}$ Department of Energy And Environmental Engineering University of Energy and Natural Resources Sunyani,
}

\begin{abstract}
Renewable energies represent a foundation to steer the energy system in the direction of sustainability and supply security in every Country. China has a huge undeveloped potential in the field of renewable energy. The Country is the leading in hydropower development all over the world with the world's leader in hydropower scale and project capacity development. Renewable energies (RE) represent a foundation to steer the energy system in the direction of sustainability and supply security in China. This paper briefly discusses current Renewable energy scenario in China and sustainable development strategy by the Year 2050. The paper also seeks to bring out the current state of renewable energy as well as the future projections of Renewable Energy in china together with recognizing the difficulties confronting full scale of its development with appropriate solutions. Measures to address these difficulties and also respond to increasing world pressure for reduction of greenhouse gas emissions has also been discussed. Conclusion was drawn on the role of the Government in the Renewable Energy development in the Country as well as emission control.
\end{abstract}

Keywords: Renewable energy, potential, energy consumption, Hydropower, Wind power, solar power

\section{Introduction}

With the rapid development of China's economy, energy consumption is increasing. It is estimated that China's primary energy demand will reach 480 million tons of standard coal by 2020 , but fossil fuels will only meet $70 \%$ of demand [1]. China is working to reduce carbon dioxide emissions by 60 percent per unit of gross domestic product by 2030 levels compared to 2005 levels [2]. Pressure to meet China's energy needs and reduce greenhouse gas emissions, China was forced to vigorously promote renewable energy (REPG), which in recent years has made rapid development. As shown in Figure 1, respectively, as shown in Table 1, and installed by the installed capacity of renewable energy capacity increased from 2010 to 2014 at the end of $2014,22 \%$ of the total electricity produced by renewable energy generated by electricity China [3]. In particular, China's cumulative installed capacity of wind power from $41.8 \mathrm{GW}$, 2014 increased $2010 \mathrm{e} 114,8 \mathrm{GW}$, leading the world for five consecutive years [4,5]. To understand the rapid growth of this, it is necessary to investigate how the Chinese government encourages the development of the industry REPG. The existing research shows that the incentive policy is an important force to promote the rapid development of the Chinese REPG [6,7]. There have been some studies on China's REPG incentive policy. For example, Kang et al. He systematically analyzed the policies and regulations promulgated in the Eleventh Five-Year Plan "Five-Year Plan" to promote wind power industry in China [8]. Zeng et al. He pointed out that China issued the REPG incentive policy between 2005 and 2011 and proposed policy recommendations [9]. Zhao and others. Incentive policies have analyzed and discussed the four types of incentive policies, namely, the fiscal policy of subsidizing policies and deducting tax exemption, tariff preferential policies and technical support, and the impact of

\footnotetext{
* Manuscript received February 1, 2018; revised July 5, 2018.

Corresponding author. E-mail address: adudaniel39@yahoo.com.

doi: 10.12720 /sgce.7.3.218-224
} 
incentive policies on the structure of power generation in China. Similarly, Liu et al. He divided China's current renewable energy policy into several categories, including development planning, industry guidance and technical support, cost sharing, price incentives, legal responsibility and promotion [10].

\subsection{Current situation of renewable energy resources in China}

Renewable energy is increasingly becoming part of a large global energy structure, especially in the energy sector. According to "World Energy Outlook 2015" (International Energy Agency, IEA), the global share of renewable energy was $22 \%$ as at 2015 with an increase expectation of $31 \%$ by 2035 [11]. The use of renewable energy has in recent years been a concerned to China. Renewable energy grew over $15.1 \%$ in 2014. Chinese renewables now account for $16.7 \%$ of the global total, up from $1.2 \%$ just ten years ago [12]. According to the 13th Five-Year Plan (2015-2020), non-fossil fuel energy is supposed to account for $15 \%$ of the total primary energy consumption by 2020. In China, grid integrated wind, solar, and hydro power generation were 96.57 million $\mathrm{kW}, 24.96$ million $\mathrm{kW}$, and 304.86 million $\mathrm{kW}$ in 2014, respectively. Renewable energy power generation in China has grown rapidly in recent years. China mounted out some strategies in their 10th five-year plan that will help increase the installed capacity renewable energy in diverse energy sectors in this program, they sought to increase the annual solar heating of hot water 11 million square meters, whereas the increase in solar cell production to 53MW. In the field of wind energy, it plans to increase its production capacity to $1.2 \mathrm{GW}$ and to increase bioenergy to provide fuel to 2 billion square meters. In order to achieve some of these goals in 2003, the government passed the Renewable Energy Law which aims to stimulate policy laws to promote the development of renewable energy technologies while providing market opportunities for renewable energy companies to provide local governments, businesses and individuals to promote and use both renewable energy [13]. Biomass is anticipated to contribute somewhere between $15 \%$ and $50 \%$ of the world's primary energy consumption by the year 2050 [14]. Biomass in China is a larger energy source than most would think because of the huge rural population. $80 \%$ of biomass energy is located in rural China with the principle source being crop residue [15]. The Chinese government is making great strides to develop rural renewable energy since biomass is a good already established. The government has begun to promote the development of biomass energy to achieve multiple projects at the national level. They participated in the planting and reforestation program in Wuhan, Guangdong Province. Figure 1 below shows renewable capacity growth by regions.

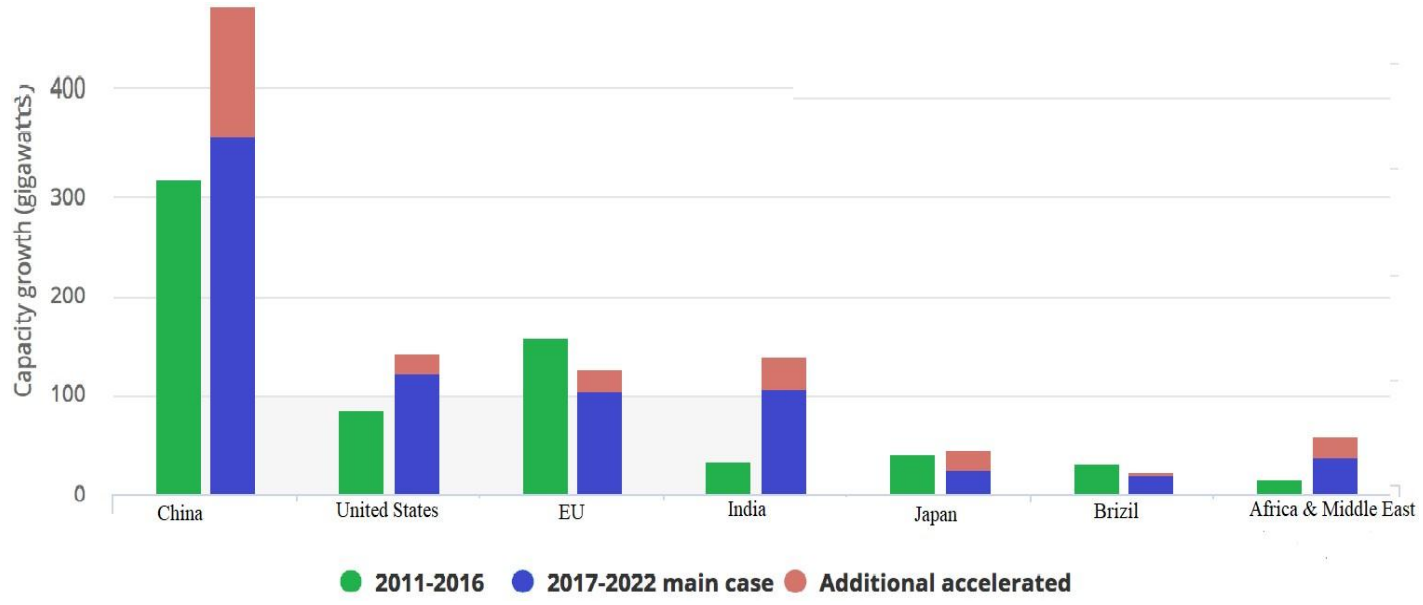

Fig. 1. Renewable Energy growth by region/Country

\section{Renewable Energy Potential}

China has a huge undeveloped potential in the field of renewable energy, and the government has recently been aware of these resources and has begun to take steps to take advantage of that potential. 
Through a study by Research and Markets Ltd, the company found that China plans to spend nearly 23\% of global investment, around $\$ 1.2$ trillion, on renewable energy from 2005 to 2030. According to the same report, the government has set goals for quite a lot of different renewable energy sectors. Is hydropower, which is currently the largest source of renewable energy in China is expected to attain a capacity of $300 \mathrm{GW}$ by 2020 . Wind which is also another powerful potential source is expected to attain $30 \mathrm{GW}$ in 2020. Biomass is anticipated to also reach $30 \mathrm{GW}$ in 2020 whereas Solar is anticipated to reach $1.8 \mathrm{GW}$ by 2020 . If China is able to achieve all these targets, it will produce a new renewable energy capacity of $362 \mathrm{GW}$. According to IEA new solar PV capacity grew by 50\% in 2016 with China accounting for nearly half of the global expansion.it has projected that renewable electricity capacity should increase by $43 \%$ by 2022 . China continued to be the undoubted leader of renewable electricity capacity expansion over the forecast period with over $360 \mathrm{GW}$ of capacity thus $40 \%$ of the global total. China has in recent one decade taken the leading position in the global new energy market, having the world's largest wind power capacity and the world's fastest-growing solar PV power generation sector. The country recorded a combined on-grid wind power and solar PV power generation installed capacity of more than $100 \mathrm{GW}$ for 2014 , generating almost 180 billion $\mathrm{kWh}$ of electricity during the year, comparable to the annual consumption capacity of electricity of a moderately developed Chinese province. During the first 11 months of 2015, the countries installed capacity connected to the grid of new energy reached $146 \mathrm{GW}$, accounting for $12.4 \%$ of total installed capacity in the Country. Xinjiang, one of the fastest-growing provinces in China's new energy sector, has reached a total new energy power installation capacity of over $60 \mathrm{GW}$, including $10.2 \mathrm{GW}$ of wind power installed capacity and $5.03 \mathrm{GW}$ of PV power generation capacity. Xinjiang also planned to add extra $26 \mathrm{GW}$ in new power installation capacity in 2016, of which more than $14 \mathrm{GW}$ was to be provided from new energy sources (16), (17). Jiangsu province deployed 4.6 GW in offshore wind power capacity in 2010, ranking the region first in Asia. Research shows that the province is home to $34.7 \mathrm{GW}$ of wind energy resources in total. The province sits on 21 GW of developable coastal wind power capacity, with $14.7 \mathrm{GW}$ or $70 \%$ located in and around the city of Yancheng (including $1.7 \mathrm{GW}$ onshore and $13 \mathrm{GW}$ offshore). Jiangsu province as of June 2015, swanked a clean-energy power capacity of $9.76 \mathrm{GW}$, with $3.63 \mathrm{GW}$ coming from wind. The province has the most offshore wind power capacity of any province in China (18).

\subsection{Hydropower}

China is the leading country of hydropower development in the world having the world's highest hydropower scale and project capacity development, with the largest hydropower station in the world's situated along the Yangtze River. China had 117GW of installed capacity in 2005 with the aforementioned of $300 \mathrm{GW}$ by 2030. the World Watch Institute said that China has hydropower potential capacity of $500 \mathrm{GW}$ [19]. In the company of nuclear power, wind energy, hydropower seems to be the government's priority to the national energy agenda, because "technology is mature, China has quite rich experience in this area, in consort with an equitably well-developed domestic industry [20]. At present, China has a capacity of 760 megawatts to $22.5 \mathrm{GW}$, which can be accommodated in about 5 dams, most of which are distributed in Sichuan and Yunnan. There are currently about 11 dams under construction, all before 2020 [21]. With hydropower, wind power has a great opportunity to become a major source of renewable energy in China.

\subsection{China's renewable energy goals by 2050}

There was an increased in the total consumption of energy in China at an average annual rate of $7.5 \%$ flanked by 2001 and 2015 and got to 4.26 and 4.30 billion in 2014 and 2015, correspondingly. China has huge renewable energy resources and has made quick advancement in the development of renewable energy. There have been an increased in the installations of solar and wind power capacity over the past period between (2006-2015), at a yearly average rate of $100.3 \%$ and $58.2 \%$, respectively thus, $(94.1 \%$ as 
well as $29.1 \%$ throughout 2011-2015) (Fig. 2). Renewable electricity from hydro19.6\%, -, solar22.4\% and wind $23.9 \%$ all accounted for a total electricity generation in China for 2013, 2014 and 2015, respectively [22]

Table 1. China's renewable energy development goals by 2050a.

\begin{tabular}{|c|c|c|c|c|c|c|c|c|c|}
\hline \multirow{2}{*}{$\begin{array}{l}2 . \\
\text { 12. Power generation } \\
\text { capacity(GWe) }\end{array}$} & \multirow{2}{*}{$\begin{array}{l}\text { 3. } 2015 \\
\text { 4. }(\mathrm{CND} \\
\text { 5. } \mathrm{RC},) 20 \\
\text { 6. } 11 \\
\end{array}$} & \multirow{2}{*}{\multicolumn{4}{|c|}{$\begin{array}{l}\text { 7. } \frac{2030}{\text { 8. }} \text { G1 } \quad \text { G2 } \quad \text { G3 } \quad \text { G4 }\end{array}$}} & \multirow{2}{*}{$\begin{array}{l}\text { 9. } 2050 \\
\text { 10. G1 }\end{array}$} & \multirow[b]{2}{*}{ G2 G3 } & \multirow[b]{2}{*}{ G4 } & \multirow[t]{2}{*}{11.} \\
\hline & & & & & & & & & \\
\hline 13. Hydropower & 14. 260 & 15. 403 & 16. 430 & 17. 453 & 18. 400 & 19. 440 & 20. 510 & 21.530 & 22.530 \\
\hline 23. Wind power & 24. 100 & 25.120 & 26. 180 & 27. 300 & 28.400 & 29. 300 & 30. 500 & 31.800 & $\begin{array}{l}\text { 32. } 100 \\
33.0\end{array}$ \\
\hline 34. Solar power & 35.21 & 36.50 & 37. 100 & 38. 200 & 39.450 & 40.500 & 41.800 & 42. 1000 & $\begin{array}{l}\text { 43. } 130 \\
44.0\end{array}$ \\
\hline $\begin{array}{l}\text { 45. Geothermal } \\
\text { power }\end{array}$ & 46. 13 & 47. 0.5 & 48. 0.5 & 49. 0.5 & 50.5 & 51. 1.5 & 52.1 .5 & 53. 1.5 & 54. 50 \\
\hline 55. Biomass power & 56. 0.1 & 57. 20 & 58.20 & 59.20 & 60.35 & 61.10 & 62.10 & 63.10 & 64.35 \\
\hline 65. Ocean power & 66.0 .05 & 67.1 & 68.1 & 69.1 & 70.1 & 71.10 & 72. 10 & 73. 10 & 74. 10 \\
\hline 75. Biogas & 76. 17.5 & 77. 62.9 & $\begin{array}{l}78.62 . \\
79.9\end{array}$ & 80.62 .9 & 81.61 & 82.78 .6 & 83.78 .6 & 84.78 .6 & 85.108 \\
\hline 86. Biomass briquette & 87.50 & 88. 14.3 & $\begin{array}{l}89.21 . \\
90.4\end{array}$ & 91.35 .7 & 92.25 & 93.21 .4 & 94.35 .7 & 95.57 .1 & 96.40 \\
\hline 97. Geotherm & 98.15 & 99. 20.5 & $\begin{array}{l}100.20 . \\
101.5\end{array}$ & 102.20 .5 & 103. 100 & 104. 41 & 105.41 & 106. 41 & 107. 200 \\
\hline 108. Ethanol/biodiesel & 109.5 & 110.44 .1 & $\begin{array}{l}111.77 . \\
112.9\end{array}$ & $\begin{array}{l}113.101 . \\
114.1\end{array}$ & $\begin{array}{l}115.56 . \\
116.6\end{array}$ & 117. 77.9 & 118.134 .9 & 119.168 .6 & 120.193 \\
\hline $\begin{array}{l}\text { 121. Total renewables } \\
\text { 122. (billion tce) }\end{array}$ & 123. 0.48 & 124. 0.73 & $\begin{array}{l}125.0 .8 \\
126.9 \\
\end{array}$ & 127. 1.1 & 128.1 .4 & 129.1 .14 & 130. 1.54 & 131.1 .93 & 132. 2.6 \\
\hline $\begin{array}{ll}\text { 133. Total } & \text { energy } \\
\text { consumption } & \text { (billion } \\
\text { tce) } & \end{array}$ & 134. 4.2 & 135.4 .5 & 136.4 .5 & 137. 4.5 & 138.5 .5 & 139.5 & 140.5 & 141.5 & 142.5 .8 \\
\hline $\begin{array}{l}\text { 143. Share } \\
\text { renewables }(\%)\end{array}$ & 144. 114 & 145.16 .3 & $\begin{array}{l}146.19 . \\
147.8\end{array}$ & 148. 24.4 & 149.25 & 150. 22.8 & 151.30 .8 & 152.38 .5 & 153.45 \\
\hline 154. & 155. & 156. & 157. & 158. & 159. & 160. & 161. & 162. & 163. \\
\hline
\end{tabular}

a G represents Goal and G1-G3 are quoted from [23]

b tce stands for ton of standard coal equivalent. c China's Energy Development Strategy Action Plan for 2014-2020 released on November 19, 2014

With the establishment of a competitive system for the renewable energy industries with the world's largest market, China holds great potential. Research Committee China's energy strategy, long-term development [23] proposed renewable energy targets (G1-G3) in three cases of 2020, 2030 and 2050 (Table 1). G1 is relatively conservative, mainly based on normal growth and development without taking into account the serious greenhouse gas emission reduction. While G3 relies heavily on driving progress, while policy responses to climate change. G3's situation requires considerable research and development 
in the field of wind energy, solar energy and biofuels. G1 and G3 resources between the commitment (G2) potentials, environmental constraints, and overall social costs into account. G1-G3 are based on the projection of 4.0, 4.5 and 5.0 billion tce for the total energy consumption by 2020, 2030 and 2050, respectively. Under these three scenarios, the share of China's renewable energy would be estimated $22.8 \%, 30.8 \%$ and $38.5 \%$ by 2050 . This projection is under-estimated in terms of China's population growth, urbanization rate and energy consumption trend. Under a high renewable energy uptake scenario, the share of China's renewable energy is projected to account for $62 \%$ of total energy consumption and $86 \%$ of total power generation by 2050 [24]

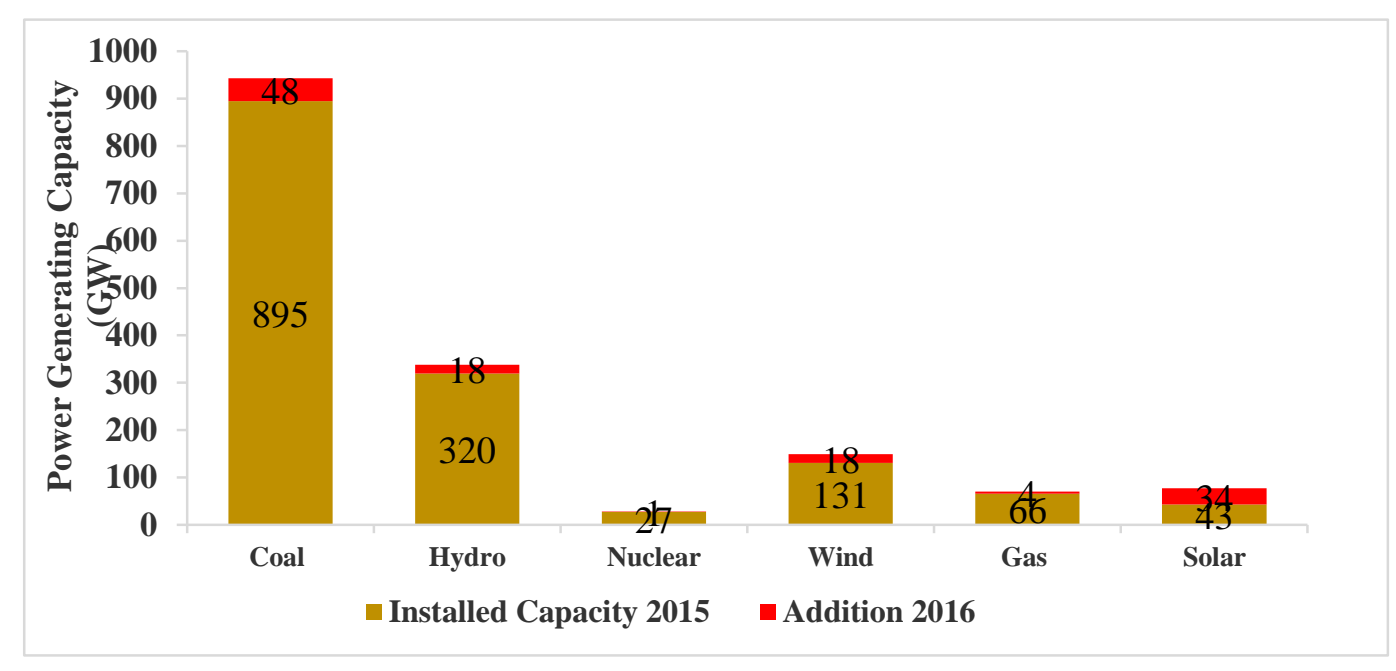

Fig 2. The installed power generating capacity in China together with the additions in 2016 in GW [18]

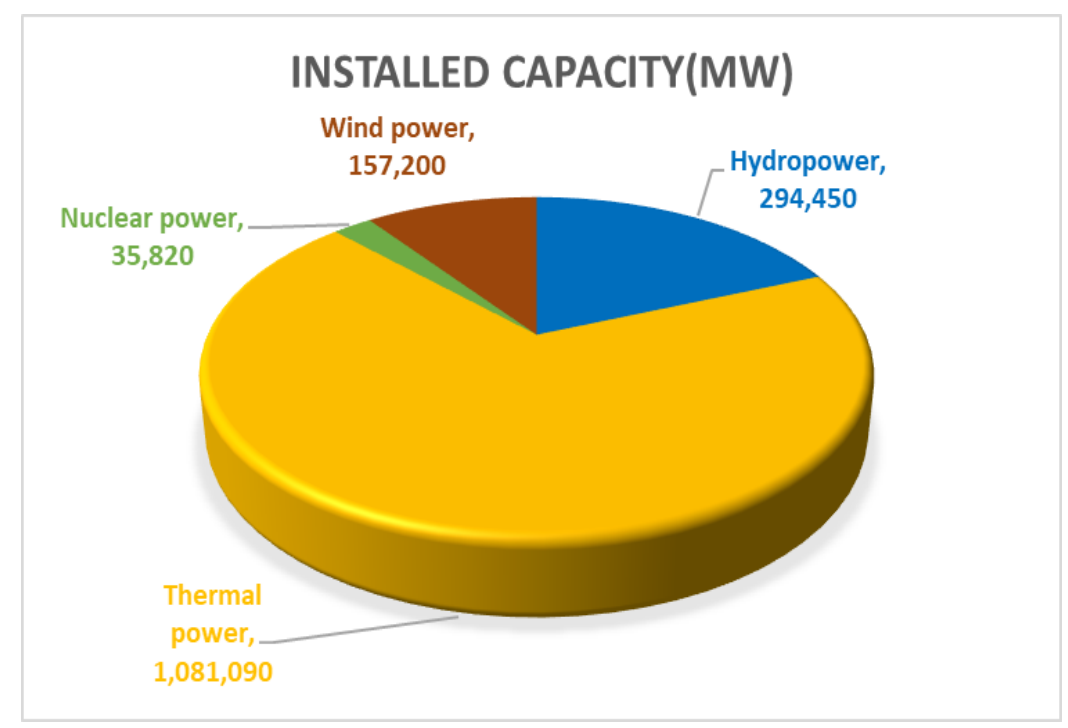

Fig. 3. Renewable energy installed capacity in china 2017.

*Thermal includes coal, gas, oil, and biomass 


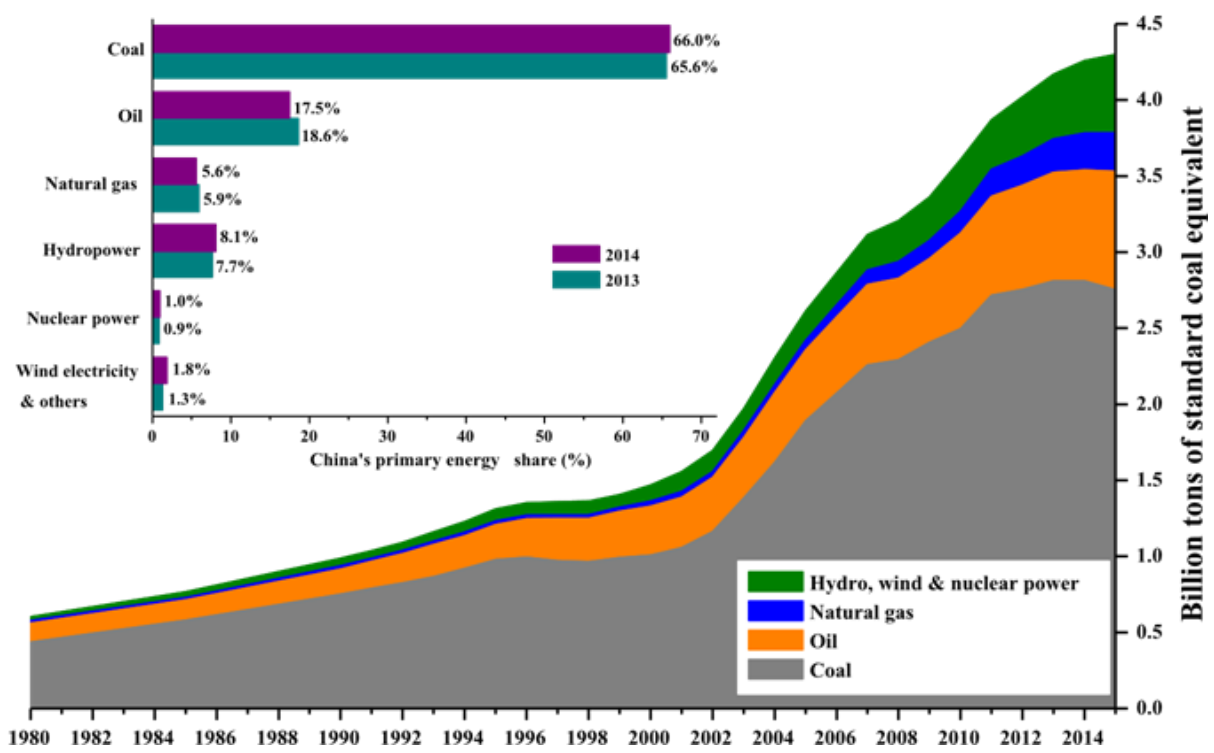

Fig. 4. China's primary energy consumption since 1980 - 2015. [25,26]

\section{Conclusion}

China has great potential for several different industries in renewable energy. Its great potential is in the mature industry hydropower. There is also a huge undeveloped potential in wind, solar and biomass. The Chinese government must stop putting coal-fired power plants online and begin to eliminate old coalfired power plants to speed up the development of clean energy. The Chinese government is making great progress and is beginning to see the importance of this, but there is still plenty of potential for untapped renewable energy. On the contrary, following the rest of the world, the Chinese government's clean energy resources, where you can come forward, lead the rest of the world in the development of renewable energy. Rather than the rest of the world criticize China for its lack of environmental responsibility, the Chinese government can now make changes and other parts of the international community can honor and follow China's environmental responsibility.

\section{Acknowledgement}

We thank National Natural Science Foundation of China form their financial support.

\section{Authors' Contributions}

Jinfeng and Adu Daniel abstracted the paper and delve into the topic. All authors contributed towards the writing and editing of the manuscript.

\section{Reference}

[1] Zhao ZY, Zhang SY, Hubbard B, Yao X. The emergence of the solar photovoltaic power industry in China, Renew. Sustain Energy Rev. 21 (2013) 229e236.

[2] [Online], The speech at the opening ceremony of the Paris Conference on climate change made by Xi Jinping, 2015, http://news.xinhuanet.com/201512/01/c_1117309642.htm.

[3] [Online], The electricity generated by renewable energy has amounted to 1200 billion kWh, 2015. http://www.chinacir.com.cn/2015_sjkx/481827. shtml.

[4] Zhang SF, Li XM. Large scale wind power integration in China: analysis from a policy perspective, Renew. Sustain Energy Rev. vol. 16, no. 2, (2012) 1110e1115.

[5] [Online], Top Ten Countries of Cumulative Installed Capacity of Wind Power in 2014, 2015, 
http://www.cnwp.org.cn/ziliao/show.php?itemid1/41195.

[6] Ouyang XL, Lin BQ. Levelized costofelectricity (LCOE) of renewable energies and required subsidies in China. Energy Policy, 70 (2014) 64e73.

[7] Hu Z, Wang JH, Byrne J, Kurdgelashvili L. Review of wind power tariff policies in China. Energy Policy, 53 (2013) 41 e50.

[8] Kang JJ, Yuan JH, Hu ZG, Xu Y. Review on wind power development and relevant policies in China during the 11th fiveyear-plan period. Renew. Sustain Energy Rev.16 (4) (2012) 1907e1915.

[9] Zeng M, Li C, Zhou LS, Progress and prospective on the police system of renewable energy in China. Renew. Sustain Energy Rev. 20 (2013) 36e44.

[10] Liu LQ, Liu CX, Wang JS. Deliberating on renewable and sustainable energy policies in China. Renew. Sustain Energy Rev. 17 (2013) 191e198.

[11] IEA. World energy outlook 2013. 2013.

[12] BP. BP statistical review of China. London: BP; 2016.

[13] "Renewable Energy in China: Renewable Energy Policy in China Overview". National Renewable Energy Laboratory. www.nrel.gov/docs/fy04osti/35786.pdf

[14] Kumar A, Kumar K, Kaushik N, Sharma S, Mishra S. Renewable energy in India: current status and future potentials. Renew Sustain Energy Rev 2010; 14:2434-42. 15.

[15] Yuanyuan L. New Energy Installed Capacity in China Reached 146 GW in 2015, RenewableEnergyWorld.com, 2017

[16] IEA: New era' in solar energy fueling growth in renewables ,2017

[17] By Liu Yuanyuan, China Plans Offshore Wind Power Plants in Northern Jiangsu Province, 2015 RenewableEnergyWorld.com2017

[18] Thompson R. China: Clean and Renewable Energy Report to 2010.

[19] Jiangxiang Y. Hydropower: A Viable Solution for China's Energy Future? 2007. World watch Institute. http://www.worldwatch.org/node/4908

[20] "Dams in China". Wikipedia.org. http://en.wikipedia.org/wiki/Category:Dams_in_China

[21] CEC, 2014. Power statistics basic data list in 2013. Available from: 〈http://www.cec.org.cn/guihuayutongji/tongjxinxi/niandushuju/2015-03-06/134849.html〉. China Electricity Council.

[22] CMLTSEDSG, 2011. Studies on China's Middle- and long-term Strategic Energy Development (2030 and 2050): renewable Energy. Study Group. Science Press, Beijing.

[23] ERINDRC, 2015. China 2050 High Renewable Energy Penetration Scenario and Roadmap Study. Energy Research Institute of National Development and Reform Commission, Beijing.

[24] "Wind Power in China". Eco World. http://www.ecoworld.com/fuels/wind-power-inchina.html

[25] CEC, 2016. Power statistics basic data list in 2015. Available from: 〈http://www.cec.org.cn/guihuayutongji/tongjxinxi/niandushuju/2016-09-22/158761.html〉. China Electricity Council. 